\title{
Development of a Mathematical Model for Precise Temperature Measurement in Geoinformation Systems for Monitoring Individual Heat Consumption In Apartment Buildings
}

\author{
Andrey Aleksandrovich Larchikov*1, Aleksandr Viktorovich Larchikov¹, Dmitry Borisovich Rygalin', \\ ${ }^{I}$ Federal State Autonomous Educational Institution of Higher Education National Research University "Moscow Institute of Electronic \\ Technology", National Research University of Electronic Technology, Bldg. 1, Shokin Square, Zelenograd, Moscow, Russia, 124498 \\ *Corresponding author E-mail: andrej.larchikov@bk.ru
}

\begin{abstract}
One of the main energy saving objectives is to find methods for metering individual heat consumption in each apartment of an apartment building. Achievements in the area of microprocessor devices made it possible to create a new type of measurement and control systems for monitoring and metering energy resources. Newly developed heat meters are the ground for fundamental changes in energy saving and energy efficiency. Apartment buildings are heated by various hot water distribution systems, for which it is not always possible to use conventional heat meters. The ambiguity related to the parameters of heat meters can adversely affect the estimation of heat consumption by each apartment in an apartment building. This paper is aimed at analyzing a new contact temperature measurement method and means used to create a system for heat monitoring and metering in an apartment building. The developed system can be used to meter energy resources of facilities distributed in a specific area, with geographic referencing to each facility. This makes it possible to remotely monitor heat energy consumption, which makes the energy consumption control system much more transparent and ensures public control. The system gathers data from a large number of users, processes data in real time and promptly responds to users' requests based on recent developments in information technology. An important advantage of the developed system is that it can be used to anticipate emergency situations taking into account various factors, such as weather conditions and the age of buildings. Due to all of the above, the system can be used in the future not only in Russia but also abroad.
\end{abstract}

Keywords: precision temperature measurement, geoinformation monitoring system; heat energy; individual heat consumption metering.

\section{Introduction}

As a result of depletion of natural resources, heat costs are rising globally. The processes of production, transmission, and consumption of resources, each in its own way, have severe impact on the environment. Over recent years, the increasing concentration of $\mathrm{CO}_{2}$ in the atmosphere has been the main climatic issue. One of the reasons for this is carbon dioxide emissions from the combustion of fuels, such as coal, gas and oil products. In order to reduce the harmful effects, it is necessary to improve technology, introduce more advanced and intelligent equipment and increase energy efficiency at all stages, from production to final consumption. $\mathrm{CO}_{2}$ is mainly emitted from fuel combustion when heat is generated in the housing and utility sector. Therefore, heat saving is the main goal for reducing $\mathrm{CO}_{2}$ emissions and the adverse impact on the environment. To solve this issue, it is necessary to make changes in energy networks related to introducing digital technology and increasing consumer involvement in the management of energy consumption [1]. Apartment buildings are usually heated by obsolete central heating systems. One of the main goals for reducing $\mathrm{CO}_{2}$ emissions is to redesign or improve the heat supply system in apartment buildings, which can be achieved either by replacing outdated thermohydraulic components and devices or by optimizing their performance and control. The distribution of heat energy in apartment buildings based on the estimation of actual individual costs of heat energy gives a hefty boost to residents to optimize heating management in order to save energy and money.Russia is the biggest heat supplier in the world (Figure 1) in terms of the amount of produced heat, development of heat-and-power generation, length of heat networks, and fuel consumption for heat production. However, this sector of the fuel and energy industry of the country has remained totally unstructured due to lack of its integration. Today, the heat supply sector exists in the form of separate branches, which, unlike other sectors of the fuel and energy industry, do not have a single engineering, structural and investment, economic and organizational policy. In general, the heat economy of Russia is a set of local district and distributed heat supply systems spread across settlements and industrial enterprises. However, the heat economy is nationwide, and therefore it should be regarded as a sector of the fuel and energy industry with its internal and external material, financial, engineering and process and organizational relations [2].

In order to perform effectively, the district heat supply system needs both a sales market and a "cheap local energy source", which can be represented by heat generated along with electricity (Denmark and Finland), geothermal energy (Iceland), waste heat from incineration plants (Norway) or a combination of various sources of energy (Sweden). Denmark, where $80 \%$ of the population resides in urban areas, is a good example of rich experience in and traditions of using CHP for district heating. The country has high annual consumption of heat energy and a long heating season; almost all large power plants are located in close 
proximity to major cities. As a result, district heating is the mos common source of heat. District heating systems are used in more than 450 cities [4].

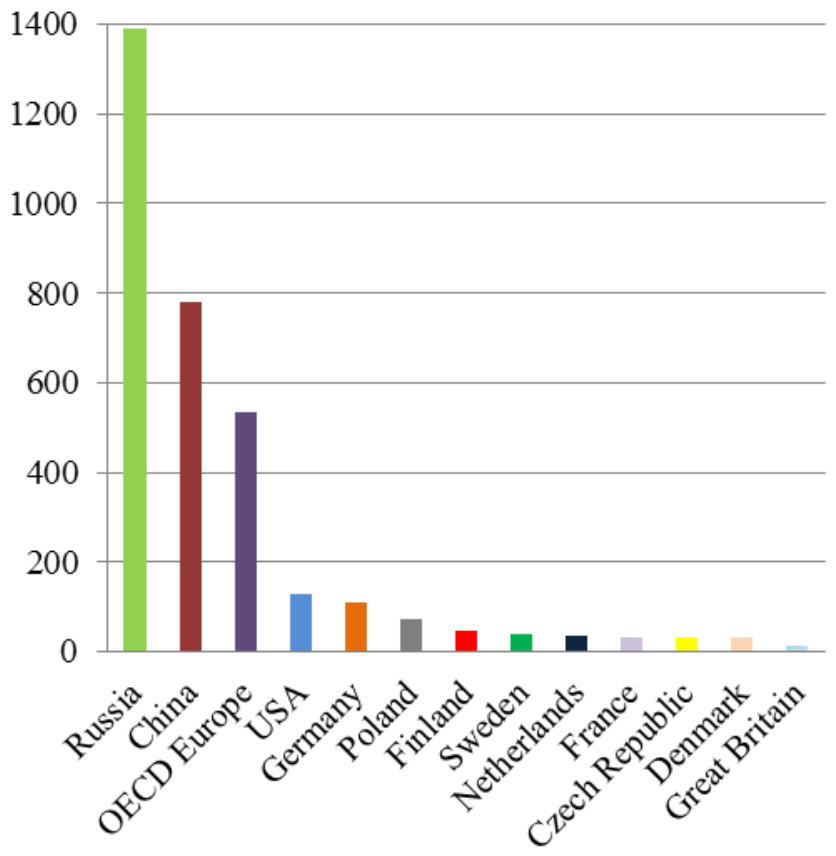

Figure 1: Heat production from central heating systems, (mln Gcal) [3].

In Copenhagen, the capital of Denmark, combined generation of heat and power energy has been used for more than 50 years. 50 stations, mainly reconstructed boiler houses; 9 different units providing a basic load, including 4 incineration plants and $4 \mathrm{CHP}$ plants, running on liquid fuel, coal or natural gas, are connected to the district heat supply system [4]. At the same time, Denmark consumes 50 times less heat than Russia (Figure 1).

The issue of monitoring and metering individual consumption of energy resources exists not only in the European Union and Russia; it is also one of the major concerns in the world. It is impossible to monitor something that is not accurately measured. An appropriate electric power metering method will allow saving a lot. Particularly, in case of individual meters, consumers will tend to save energy sources. Real-time consumption monitoring may help reduce heat costs [5].

Individual consumption metering ensures that costs of heating, hot and cold water and electricity in an apartment building are reallocated on a more equitable basis, depending on the actual consumption of resources, rather than the area of an apartment. In accordance with the Energy Efficiency Directive (EED), all EU countries shall use energy more efficiently throughout the energy chain, i.e. from production to final consumption. The main idea of the Directive is to provide energy consumers with accurate information about consumption, which will encourage them to act in an energy-saving way [6].

In EU countries, the consumption of heat energy in apartment buildings is measured using the proportional method. This method is based on measuring and integrating the temperature head between the surface of the heating (heat-exchange) unit and the air in the room, taking into account the design of the heat exchange unit and the profile of temperature distribution on its surface, thus making it possible to determine which part of heat energy is dissipated by this heating unit. The heat energy cost for heating the apartment building is proportionally allocated among the residents. Electronic devices are called proportionators. In order to determine energy consumption using proportionators, they shall be installed on each heat-exchange unit in the apartment. When using proportionators based on the time-integrated temperature head, the absolute heat energy consumed by an individual user is calculated, rather than the relative heat energy. The readings of proportionators are taken directly by visiting the apartment. Advanced systems for counting energy resources use wireless technology, while heat energy metering systems based on proportionators exclude the possibility of determining its communal cost [7].

The developed system combines high-precision electronic temperature measuring devices and maintains its high performance regardless of any changes and updates in the heat supply of buildings. The system uses a method for measuring individual heat consumption based on virtual measuring channels equipped with high-precision wireless temperature meters (WTMs). Using cloud data storages and software, the system will allow analyzing the received information, quickly obtaining all the initial data for taking decisions, and promptly responding to emergencies [5].

\section{Mathematical model of the temperature dependence of thermometric parameters of sensors}

For higher accuracy, it is preferable to directly measure the excess energy provided by the heat-transfer agent using temperature sensors, a flow meter, and a counting device. In apartment buildings with vertical heat distribution, indirect methods of measuring heat energy are used, which are based on the analysis of heat transfer from the surface of the heat-transfer agent to the environment.

For high-precision temperature measurements, the resistance thermometer (RT) is used, the main advantages of which are a wide range of operating temperatures, small size, vibration resistance, the linearity of the rated static characteristic, and a relatively high temperature resistance coefficient (TRC) [8].

Temperature measurements using the RT are made uniform through international standards, such as the "European" standard IEC 60751 (DIN/IEC EN 60751) and the "North American" standard ASTM 1137. There are also other standards, while the above mentioned are more common [9]. GOST R 8.625-2006 "Platinum, Copper and Nickel Resistance Thermometers" was applied in Russia until 2011, which corresponded to the international standard IEC 60751 in terms of determining the temperature dependence of resistance and tolerances for platinum sensing elements (SEs) and RTs with a TRC of $\alpha=0.00385{ }^{\circ} \mathrm{C}-1$. The standard sets general technical requirements for RTs [10]. Today, GOST 6651-2009 "Platinum, Copper and Nickel Resistive Temperature Transducers", a new interstate standard, is applied in Russia. GOST 6651-2009 has been revised in accordance with the International Temperature Scale ITS-90 [11].

Platinum resistance thermometers (PRTs) are considered to be the most consistent and reliable contact temperature sensors, and in this case, it would be reasonable to apply them. When measuring temperature using the PRT, it is necessary to choose a mathematical model to convert resistance of the sensor to temperature. Mathematical models describing the temperature dependences of thermometric parameters of sensors and hardware and software used for their implementation in electronic thermometers largely determine the temperature measurement error. The temperature calculation for PRTs based on the standard 9th and 15th degree polynomials has been offered in ITS-90 [1214].

PRTs are used in industrial and laboratory environments in the range from $260{ }^{\circ} \mathrm{C}$ to $750{ }^{\circ} \mathrm{C}$. They are made in the form of 0.005 to $0.1 \mathrm{~mm}$ wires. The temperature coefficient, rated resistance, measured temperature range, and rated static characteristic (RSC) are the main parameters that determine applications and connection diagrams of PRTs.

The RT temperature coefficient describes the temperature dependence of resistance: 
$\alpha=(\mathrm{R} 100-\mathrm{R} 0) / 100 \mathrm{R} 100$

where R100, R0 are RT resistance values from RSC at temperatures of 100 and $0{ }^{\circ} \mathrm{C}$, respectively. The temperature coefficient value can be found in GOST R 8.625-2006 [8, 10].

RSC is the temperature dependence of RT resistance. For PRTs, this dependence can be represented by two equations for two temperature ranges:

$-200{ }^{\circ} \mathrm{C}$ to $0{ }^{\circ} \mathrm{C}$, the formula is written as $=\mathrm{R} 0[1+\mathrm{At}+\mathrm{Bt} 2+\mathrm{C}$ (t-100) t3] (2)

$0{ }^{\circ} \mathrm{C}$ to $+850{ }^{\circ} \mathrm{C}$, the formula is written as $\mathrm{Rt}=\mathrm{R} 0(1+\mathrm{At}+\mathrm{Bt} 2)$ (3)

where $\mathrm{Rt}$ is the PRT resistance, $\mathrm{Ohm}$, at a temperature of $\mathrm{t}{ }^{\circ} \mathrm{C}$; $\mathrm{R} 0$ is the PRT resistance, Ohm, at a temperature of $0{ }^{\circ} \mathrm{C}$; the factors $\mathrm{A}, \mathrm{B}$ and $\mathrm{C}$ are determined on a trial basis and differ depending on a TRC $[8,10]$.

The WTM uses a platinum thin-film thermistor Pt-1000 by Heraeus Sensor Technology. When operating thermistors Pt-1000 for 5 years at a temperature of $200{ }^{\circ} \mathrm{C}$, the electrical resistance R0 changes by less than $0.04 \%$ at

$0{ }^{\circ} \mathrm{C}$. The accuracy of temperature measurements using the WTM will be determined by a mathematical model that describes temperature changes in physical parameters of sensors. However, the temperature dependence of platinum resistance cannot be described by a simple function unified for all platinum thermometers. Therefore, if platinum thermistors are used, it is necessary to choose the optimal mathematical model for converting electrical resistance of the sensor to temperature, while ensuring the appropriate accuracy [13].

In the course of mathematical modeling of temperature dependences of thermometric parameters of platinum temperature sensors, a mathematical model has been defined that accurately describes the dependence of sensor parameters in the operating temperature range. In heating systems, such a large temperature range is not needed, and therefore the mathematical modeling of the process has been carried out for the operating temperature range of $-10{ }^{\circ} \mathrm{C}$ to $100{ }^{\circ} \mathrm{C}$. The mathematical model shall have a minimum number of computing operations. Thus, the following formula $[13,15]$ has been proposed:

$\mathrm{Rt}=\mathrm{R} 0(\mathrm{~A}-\mathrm{Ct}) /(\mathrm{Bt}-1)(4)$

where Rt is the PRT resistance, $\mathrm{Ohm}$, at the current temperature of $\mathrm{t}^{\circ} \mathrm{C}$; R0 is the PRT resistance, $\mathrm{Ohm}$, at a temperature of $0{ }^{\circ} \mathrm{C}$; the factors $\mathrm{A}, \mathrm{B}$ and $\mathrm{C}$ are some constant coefficients determined by standard tables for the value $\mathrm{R}=\mathrm{f}(\mathrm{t})$, as specified in GOST $\mathrm{R}$ 8.625-2006 [10, 15].

Using the formula (4), the mathematical modeling of the temperature dependence of the sensing element with $\mathrm{Rt} / \mathrm{R} 0=$ 1.385 at a temperature of $100{ }^{\circ} \mathrm{C}$ has been carried out. It showed that this model ensures the temperature calculation error of \pm 0.01 ${ }^{\circ} \mathrm{C}$ in the range of 0 to $100{ }^{\circ} \mathrm{C}$, with an error increase up to \pm 0.06 ${ }^{\circ} \mathrm{C}$ at the temperature range borders of -60 to $+200{ }^{\circ} \mathrm{C}$. This mathematical model is implemented in WTMs, which can be used for temperature measurements in the range of $5{ }^{\circ} \mathrm{C}$ to $95{ }^{\circ} \mathrm{C}$. The margin of the allowable absolute error of temperature measurement is not more than $\pm 0.05{ }^{\circ} \mathrm{C}$. This temperature range is determined by the temperature of the heat-transfer agent in heating systems [13-15].

The WTM (Figure 2) includes an electronic temperature measuring device and a receiver-transmitter. The received data are transmitted to the base station over a radio channel for further processing of the results $[5,16]$.
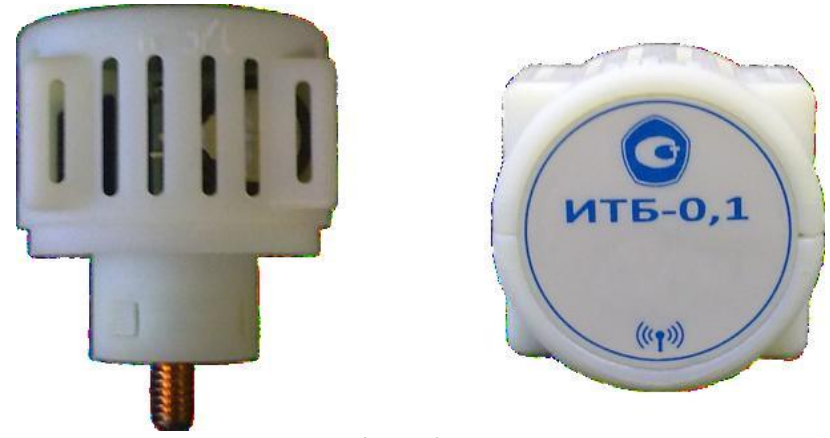

Figure 2: WTM

The WTM consists of the following: a sensing element, i.e. RT; an analog-to-digital converter; a microcontroller; a radio transceiver, an antenna and a power supply unit. There is a reed switch inside the housing, which is activated by means of a magnet in order to switch on/off the WTM. The main function of the WTM is to provide temperature measurement and analog-to-digital conversion of raw information (temperature values) from the PRT [5].

The primary transducer module is based on the bridge circuit. A platinum film-type thermometer (GOST R 8.625-2006), with an individual calibration characteristic, mounted in the heatconducting probe, is used as a sensing element. Each sensing element is subject to individual calibration. At the output of the bridge circuit, voltage is measured using an analog-to-digital converter and converted to a 16-bit binary code. The output data are sent from the analog-to-digital converter to a microcontroller module, where data are stored and accumulated in the clipboard. From the clipboard, data are sent to the radio transceiver and transmitted to the local repeater over a radio channel. The main parameters and characteristics of the WTM are specified in $[5,16]$

\section{Conclusion}

The systems for recording individual heat consumption are a driving factor in solving energy saving and energy efficiency issues. Taking into account advanced technology with precision temperature measurement methods, consistency, accuracy and reproducibility are the main measurement characteristics. The accuracy of measured values and received data shall be the main feature of the system. To achieve temperature measurement accuracy, measuring devices shall be verified and calibrated. Automated systems will allow solving this issue without calibration and verification.

To measure temperature, a platinum thin-film resistance thermometer Pt-RTD 1000, as part of the bridge circuit of the WTM, has been used in the system for metering individual heat consumption. However, the fact that Pt-RTD 1000 is used cannot ensure the high accuracy of the whole system. The mathematical modeling that has been carried out allowed reaching a temperature calculation error 3-5 times lower than the allowable absolute error of temperature measurement with similar thermometers.

The WTM, which has been developed as a result, performs the following functions:

Provides accurate temperature measurement and converts temperature values from PRT using an analog-to-digital converter; Converts the analog-to-digital code into the binary code with the required accuracy, converts the binary-coded data package into the Manchester code, performs FSK modulation and amplification of the modulated signal;

Transmits measured and calculated data to the system for displaying and recording measurement results via a wireless data transmission protocol (using radio signals), as scheduled;

Receives control signals, selects frequency and amplification of the RF signal, demodulates the FSK signal, and converts the Manchester code into the binary code [5]. 


\section{Acknowledgments}

The paper has been published with the financial support of applied research and experimental developments (of the project) by the Ministry of Education and Science of the Russian Federation under Agreement No. 14.578.21.0208 dated 03/10/2016, unique identifier RFMEFI57816X0208.

\section{References}

[1] Yakushkin I.P., Larchikov A.V., \& Rygalyn D.B., Study of Thermal Processes in Envelope Structures of Heating Boiling Operating on Biofuel Using Methods of Infrared Diagnostics, Research Journal of Pharmaceutical, Biological and Chemical Sciences, 6(3), 2015, pp. 1914- 1924.

[2] Nekrasov A.S., Siniak Yu.V., Voronina S.A., Semikashev V.V., Sovremennoe sostoyanie i perspektivy razvitiya teplosnabzheniya $\mathrm{v}$ Rossii, Current State and Prospects for the Development of Heat Supply in Russia, In Otkrytyi seminar "Ekonomicheskie problemy energeticheskogo kompleksa" (seminar A.S. Nekrasova) [Public Workshop "Economic Problems of the Energy Industry" (A.S. Nekrasov Workshop)], Moscow: INP, 2012, pp. 4-5.

[3] Zhadovets E.M., O problemakh teploenergetiki [On the Issues of Heat Power Engineering], Krasnoyarsk, 2013.

[4] Osobennosti sistem teplosnabzheniya severoevropeiskikh stran (Danii, Finlyandii, Shvetsii, Norvegii i Islandii) [Features of Heat Supply Systems of North European Countries (Denmark, Finland, Sweden, Norway and Iceland)], (n.d.), from http://energetika.in.ua/ru/books/book-3/part-1/section-5/5-3

[5] Larchikova M.V., Larchikov A.V., Rygalin D.B., Development of Geographic Information System of Control and Accounting of Individual Consumption of Energy Resources in Apartment Building, International Journal of Civil Engineering and Technology (IJCIET), 8(10), 2017, pp. 1554-1564.

[6] Energy Efficiency Directive. (2012). Retrieved August 28, 2018, from https://ec.europa.eu/energy/ en/topics/energy-efficiency/energy-efficiency-directive.

[7] Larchikova M.V., Larchikov A.V., Rygalin D.B., Determining the Factual Consumption of Thermal Energy for Individual Energy Accounting in Multiapartment Buildings, International Journal of Civil Engineering and Technology (IJCIET), 8(10), 2017, pp. 1565 1575 .

[8] Andrusevich A., \& Guba A., Termometry soprotivleniya: ot teorii k praktike [Resistance Thermometers: From Theory to Practice], Komponenty i tekhnologii, 7, 2011, pp. 76-81.

[9] IEC EN 60751, Industrial Platinum Resistance Thermometers and Pl atinum Temperature Sensors (2nd ed.) International Electrotechnical Commission, 2008.

[10] GOST R 8.625-2006, Termometry soprotivleniya iz platiny, medi i nikelya [GOST R 8.625-2006. Platinum, Copper and Nickel Resistance Thermometers], Moscow: Standartinform, 2006.

[11] GOST 6651-2009, Gosudarstvennaya sistema obespecheniya edinstva izmerenii (GSI), Termopreobrazovateli soprotivleniya iz platiny, medi i nikelya, Obshchie tekhnicheskie trebovaniya metody ispytanii [GOST 6651-2009. State System for Ensuring the Uniformity of Measurements. Platinum, Copper, and Nickel Resistive Temperature Transducers. General Requirements and Test Methods], 2009, from http://docs.cntd.ru/document/1200082733.

[12] Etalony i obraztsovye sredstva izmerenii [Standards and Calibrating Instruments], (n.d.). from http://bourabai.kz/physics/4778.html.

[13] Shtern Yu.I., Kozhevnikov Ya.S., Mironov R.E., Shtern M.Yu. Karavaev I.S., Metodika i apparatno-programmnyi kompleks dlya avtomatizirovannoi kalibrovki sredstv izmerenii temperatury s besprovodnym interfeisom [Technique and Hardware and Software Package for Automated Calibration of Temperature Measuring Devices with a Wireless Interface], Izmeritelnaya tekhnika, 5, 2013, pp. 23-26.

[14] Shtern Yu.I., Kozhevnikov Ya.S., Rykov V.M. et al., Vysokotochnye elektronnye sredstva izmereniya temperatury [High-Precision Electronic Temperature Measuring Devices], In Sbornik dokladov X Mezhdunarodnoi konferentsii "Kibernetika i vysokie tekhnologii XXI veka" [Book of Reports from the X International Conference "Cybernetics and High Technology of the 21st Century"], Vol. 1, Voronezh, 2010, pp. 420-432.
[15] Shtern Yu.I., Kozhevnikov Ya.S., Rykov V.M., Mironov R.E., Matematicheskie modeli i apparatno-programmnye sredstva dlya vysokotochnykh elektronnykh izmeritelei temperatury [Mathematical Models and Hardware and Software for HighPrecision Electronic Temperature Meters], Elektronika, 1(99), 2013, pp. 10-17.

[16] Kozhevnikov Ya.S., Shtern Yu.I., Bespalov V.A., Rygalin D.B., Patent RU 2450250, Ustroistvo dlya izmereniya temperatury teplonositelya i besprovodnoi izmeritel temperatury [Patent RU 2450250. Heat Carrier Temperature Meter and Wireless Temperature Meter], 2012. 